\title{
Brenneria quercina and Serratia spp. isolated from Spanish oak trees: molecular characterization and development of PCR primers
}

\author{
C. Poza-Carrion , I. Aguilar , F. J. Gallego , Y Nunez-Moreno , E. G. Biosca , \\ R. Gonzalez', M. M. Lopez and P. Rodriguez-Palenzuela \\ Departamento de Biotecnologla-UPM, E.T.S. Ingenieros Agronomos, 28040 Madrid; Institute Nacional de Investigacion y Tecnologfa \\ Agraria y Alimentaria, Dpto. de Biotecnologfa, Ctra A-6 km 7.5, 28040 Madrid; Departamento de Genetica, Facultad de Biologfa, Universidad \\ Complutense de Madrid, Av. Complutense s./n., 28040 Madrid; Departamento de Microbiologfa y Ecologfa, Universidad de Valencia, \\ Av. Dr. Moliner 50, Burjassot 46100, Valencia; and Institute Valenciano de Investigaciones Agrarias, Moncada 46113, Valencia, Spain
}

\begin{abstract}
Brenneria quercina has been reported as one of the causal agents of oak decline in Spain. To investigate the bacterial variability of this pathogen from different Spanish oak forests, a collection of 38 bacterial isolates from seven geographic locations and from different oak species was analysed by sequencing 16S rDNA and rep-PCR fingerprinting. All Spanish isolates of $B$. quercina were grouped by rep-PCR into a homogenous cluster that differed significantly from $B$. quercina reference strains from California. 16S rDNA analysis revealed that 34 out of 38 isolates were Brenneria. However, four isolates belonged to the genus Serratia, suggesting that this bacterium could cause cankers in oak trees. The information obtained by rep-PCR fingerprint analysis was used to develop PCR primers for the sensitive and specific detection of B. quercina from infected plant tissues. Pathogenicity tests performed with Brenneria and Serratia isolates showed that both were able to grow and cause cankers in oak trees.
\end{abstract}

Keywords: drippy nut disease, Quercus ilex, Quercus pyrenaica, rep-PCR detection and diagnosis

\section{Introduction}

Brenneria quercina is the causal agent of drippy nut disease of oaks. Hildebrand \& Schroth (1967) first described it in two Quercus species (Q. agrifolia and $Q$. wislizenii) in the interior valleys of central and northern California; drippy nut was characterized by the appearance of copious bacterial ooze from the acorns, which in most cases resulted in nut abortion. Brenneria quercina seemed to be restricted to the nut of these Quercus species in California until it was reported on $Q$. pyrenaica and Q. ilex in Spain (Soria et al., 1997) as responsible for bleeding cankers in the bark and oozing from buds (Biosca et al., 2003). Strains of B. quercina were isolated from oak species in different geographic areas within Spain and characterized phenotypically (Soria et al., 1997; Biosca et al., 2003). Relationships between B. quercina and other Enterobacteriaceae were investigated by comparison of nucleotide and peptide sequences and concatenated sequences (Hauben et al., 1998a; Young \& Park, 2007).
Little is known about the incidence of the disease caused by $B$. quercina and the genetic relationships among different isolates. 16S rDNA analysis is a widespread tool to determine the phylogenetic position of a group of isolates. A considerable part of the $16 \mathrm{~S}$ rRNA gene is conserved in all bacterial genera, whereas a smaller part is variable; this enables genealogical distances to be estimated and phylogenies derived from them (Hauben etal, 1997; Kwon et al, 1997; Young etal., 2004; Ribbeck-Busch etal, 2005; Young \& Park, 2007). Using the $16 \mathrm{~S}$ rDNA sequence, species of the Brenneria genus were grouped in a cluster and its position within the Enterobacteriaceae determined (Kwon et al, 1997; Hauben etal, 1998a; Sproer etal, 1999; Brown etal, 2000; Young \& Park, 2007).

Several molecular methods are used to rapidly identify and classify pathogenic bacteria. Rep-PCR genomic fingerprinting with Enterobacteriaceae repetitive intergenic consensus (ERIC) and repetitive extragenic palindromic (REP) primer sets were developed for this purpose (Stern et al, 1984; Hulton etal, 1991; Versalovic et al, 1991; Louws et al, 1994). Rep-PCR is a powerful, sensitive and reproducible technique to characterize, detect and identify pathogenic bacteria through their 
genetic profiles (Dawson et al., 2002; Barionovi et al., 2006).

The objective of this work was to classify bacteria isolated from diseased oak trees from different sites in Spain using 16S rDNA analysis and rep-PCR analysis. A new PCR-based diagnostic test, based on the rep-PCR results for detection of $B$. quercina in plant tissues, is also reported.

\section{Materials and methods}

\section{Microbiological methods}

Sources of bacterial isolates used in this study are listed in Table 1. Isolations were made from infected material as previously described (Biosca et al., 2003). Briefly, isolations were made on King's B (KB) medium (King et al., 1954) plus cycloheximide (250 jig $\left.\mathrm{mL}^{11}\right)$, and after $48-72 \mathrm{~h}$ at $25^{\circ} \mathrm{C}$, Brenneria-like colonies were subcultured. Isolates were kept at $-80^{\circ} \mathrm{C}$ in Hogness freezing medium [final concentration: 3-6 $\mathrm{mM} \mathrm{K}_{2} \mathrm{HPO}_{4}, 1-3 \mathrm{mM}$ $\mathrm{KH}_{2} \mathrm{P0}_{4}, 1 \mathrm{mM} \mathrm{MgS0} 0_{4}, 2 \mathrm{mM}$ sodium citrate, $4-4 \%$ (v/v) glycerol]. Bacterial identification was performed using the Biolog system (Biolog Inc.) following the manufacturer's recommendations and the identification was completed according to Biosca et al. (2003). Brenneria and Serratia strains were cultivated in $\mathrm{KB}$ medium at $28^{\circ} \mathrm{C}$.

\section{Pathogenicity assays}

Three isolates were selected for the pathogenicity test: strain N-78a from $Q$. pyrenaica, IVIA-1467a from Q. pyrenaica and $\mathrm{N}-77$ from $Q$. ilex; $10 \mathrm{mM} \mathrm{MgCl}_{2}$ was used as a negative control.

Four $Q$. pyrenaica (6-7 years old) and nine $Q$. ilex (2-3 years old) trees were inoculated per bacterial strain with a suspension containing $10^{9}$ bacterial cells in $1 \mathrm{~mL}$ of $10 \mathrm{mM} \mathrm{MgCl}_{2}$, applied to a small cavity in the trunk created with a cork borer ( $2 \mathrm{~mm}$ diameter). The trees were incubated in a greenhouse $\left(28^{\circ} \mathrm{C} / 70 \% \mathrm{RH}\right)$ and 3 months after inoculation, the external bark from inoculated trees was removed from the canker; bacteria were isolated from this ooze and identified with the Biolog system.

\section{ERIC and rep-PCR genotyping}

Bacterial genomic DNA was extracted using the GenomicPrep ${ }^{\mathrm{M}}$ Cells and Tissue DNA Isolation Kit (Amersham Biosciences) following the manufacturer's instructions. PCR reactions were performed in a final volume of $25 \mathrm{flh}$ with the following components: $15 \mathrm{ng}$ DNA template, $50 \mathrm{pmol}$ oligonucleotides (ERIC or REP), 1-25 mM dNTPs, 2 U AmpliTaq Gold DNA polymerase (Applied Biosystems), 2-5 mM $\mathrm{MgCl}_{2}$, and 2-5 flh of 1Ox concentrated stock of PCR buffer. The sequence of the primers used were: ERIC-a 5'-ATGTAAGCTCCTGGGGATTCAC-3' and ERIC-b 5'-AAGTAAGTGACTGGGGTGAGCG-3' (Hulton etal, 1991); REP-a 5'-RCGYCTTATCMGCGGTAC-3' and
REP-b 5'-NNNRCGYCGNCATCMGGC-3' (Stern et al, 1984). Each primer pair was 5'-labelled with one of the following fluorescent dyes: 6-FAM for ERIC and HEX for REP (Applera).

PCR reactions were performed in a Perkin Elmer 9600 thermocycler with the following conditions: initial denaturing $\left(95^{\circ} \mathrm{C}, 7 \mathrm{~min}\right), 30$ cycles of denaturing $\left(94^{\circ} \mathrm{C}\right.$, $1 \mathrm{~min}$ ), annealing (ERIC $52^{\circ} \mathrm{C}, 1 \mathrm{~min}$; rep $44^{\circ} \mathrm{C}, 1 \mathrm{~min}$ ) and extension $\left(65^{\circ} \mathrm{C}, 8 \mathrm{~min}\right)$; and a final extension $\left(65^{\circ} \mathrm{C}\right.$, $15 \mathrm{~min}$ ) (Louws etal, 1994). Aliquots (2 jih) of PCR products were mixed with $12 \mathrm{flh}$ of formamide and 0-5 jiL of red-DNA size standard (GENESCAN-500 ROX, Applera). Samples were denatured at $94^{\circ} \mathrm{C}$ for $3 \mathrm{~min}$ and separated by capillary electrophoresis at $15 \mathrm{kV}$ for 30 min in an ABI Prism 310 DNA Sequencer (Applera). Results were analysed by using GENESCAN analysis software 3-1 (Applera). This system was used to obtain genetic profiles for each bacterial isolate. All experiments were repeated twice under the same conditions.

\section{S rDNA amplification and sequencing}

16S rDNA PCR amplification of different isolates was performed following Hauben et al. (1997): total reaction volume was $50 \mathrm{flh}$ and contained 2-5 ng of DNA template, $200 / 1 M$ dNTPs, 2-5 mM $\mathrm{MgCl}_{2}$, $2 \mathrm{U}$ of AmpliTaq Gold DNA polymerase, $50 \mathrm{pmol}$ of each oligonucleotide and $5 \mathrm{flh}$ 1Ox concentrated stock of PCR buffer. The primers used were: 16F27 5'-AGAGTTTGATCMTGGCTCAG-3' and 16R1525 5'-TTCTGCAGTCTAGAAGGAGGTGWTCCAGCC-3' (Hauben etal, 1997). Amplification was performed in a Perkin Elmer 9600 thermocycler with an initial denaturing temperature of $95^{\circ} \mathrm{C}$ for $7 \mathrm{~min}$, followed by 25 cycles of denaturation $\left(94^{\circ} \mathrm{C}, 1 \mathrm{~min}\right)$, annealing $\left(55^{\circ} \mathrm{C}, 1 \mathrm{~min}\right)$ and extension $\left(72^{\circ} \mathrm{C}, 2 \mathrm{~min}\right)$, with a final extension of $68^{\circ} \mathrm{C}$ for $7 \mathrm{~min}$ (Hauben et al, 1997). The amplified fragment was purified and sequenced in a 377 DNA automated sequencer (Perkin Elmer). Sequence alignments were performed at the internet site of the National Center for Biotechnology Information (http://www4.ncbi.nlm.nih.gov) with the BLAST network service (Altschul et al, 1997). In addition to the former primers used for amplification, another primer pair was used to complete the DNA sequence: 16R1087 5'-CTCGTTGCGGGACTTAACCC-3' and 16F530 5'-TTCGTGCCAGCAGCCGCGG-3' (Hauben etal, 1997).

\section{Data analyses}

Genetic profiles obtained by ERIC and rep-PCR from capillary separation were combined and converted into a binary matrix on the basis of presence/absence. To estimate similarity between different isolates, the simple matching algorithm was used (Nei, 1972). A dendrogram was built showing similarity between isolates after applying the UPGMA method (Sneath \& Sokal, 1973). The concordance of the similarity data obtained from the analyses of ERIC and REP primers was determined with 
Table 1 Sources of field isolates and collection strains used in this study

Isolate $^{\mathrm{a} / \text { Strain }^{\mathrm{a}}}$

Brenneria quercina field isolates:

(IVIA-1994-14, IVIA-1994-15)*

(IVIA-1251-3, IVIA-1251-5C)*

(IVIA-1442-2, IVIA-1442-8a)*

(IVIA-1467-a, IVIA-1467-h)*

(IVIA-1618-a, IVIA-1618-e) *

(IVIA-1625-1, IVIA-1625-2)*

(IVIA-1745-3, IVIA-1745-5)*

(IVIA-1915-5, IVIA-1915-14)*

(IVIA-1927-1, IVIA-1927-4)*

(IVIA-1934-1, IVIA-1934-2)*

(IVIA-1940-1, IVIA-1940-3)*

(IVIA-1958-1, IVIA-1959-1)*

(IVIA-1982-1, IVIA-1983-2)*

(IVIA-1986-6, IVIA-1986-7)*

(IVIA-1988-2b, IVIA-1988-2)*

(IVIA-1988-3b, IVIA-1988-3)*

$\mathrm{N}-76$

$\mathrm{N}-77$

Serratia spp. field isolates:

(IVIA-1251-4, IVIA-1251-5)*

(N-78-a, N-78-b)*

Collection strains:

Brenneria rubrifaciens NCPPB 2020

Brenneria nigrifluens NCPPB 564

${ }^{b}$ Pantoea agglomerans 1742-5

"Erwinia herbicola NCPPB 2971

Pectobacterium carotovorum subsp.

atrosepticurn SCRI 1001

Pectobacterium carotovorum subsp. carotovorum 312

Erwinia amylovora NCPPB 595

Erwinia rhapontici 1093-1 a

Dickey a dadanfl;AC4150

Erwinia iupinicoia 3299

Erwinia mallotivora 1818

Pantoea stewartii 2994

Brenneria salicis NCPPB 447

Brenneria alni NCPPB 3934

Pseudomonas syringae pv. tomato DC 3000

Pseudomonas syringae pv. phaseolicola

Pseudomonas syringae pv. tabaci

Brenneria quercina NCPPB 1852

Brenneria quercina NCPPB 1853

Brenneria quercina NCPPB 3077

Brenneria quercina CFBP 1266

Serratia rubidaea $868 \mathrm{~T}$

Escherichia coli DH5a
Original host

Quercus Hex (acorn) Q. Hex
(canker)
Oilex (canker)
Q. pyrenaica (canker)
Q. ilex (acorn)
Q. pyrenaica (leaf bud)
O. ilex (canker)
Q. ilex (acorn)
Q. ilex (acorn)
Q. ilex (acorn)
Q. ilex (acorn)
O. ilex (canker)
O. ilex (canker)
Q. ilex (acorn)
Q. ilex (acorn)
Q. ilex (acorn)
Q. ilex (acorn)
Q. ilex (acorn)
O. ilex (canker)
Q. pyrenaica (canker)

Juglans regia

J. regia

Olea europaea

Wisteria floribunda

Solanum tuberosum

S. tuberosum

Pyrus communis

Allium cepa

Multiple

Mallotussp.

Zea mays

Salixsp.

Alnus sp.

Lycopersicon esculentum

Phaseolus spp.

Nicotian aspp.

Quercussp.

Quercussp.

Quercussp.

Quercussp.
Geographic

origin Source ${ }^{3}$

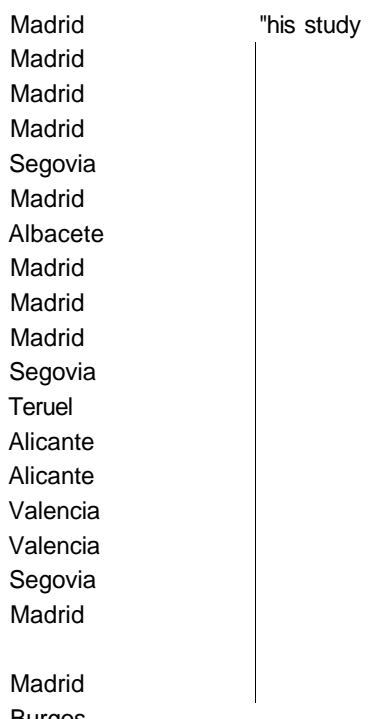

Burgos

MCPPB

MCPPB

"his study

MCPPB

3CRI

"his study

MCPPB

"his study

${ }^{a}$ IVIA, Instituto Valenciano de Investigaciones Agrarias, Valencia, Spain; NCPPB, National Collection of Plant Pathogenic Bacteria, Central Science Laboratory, York, UK; CFBP, Collection Francaise de Bacteries Phytopathogenes, Angers, France; SCRI, Scottish Crop Research Institute, Invergowrie, Dundee, UK; CECT, Coleccion Espanola de Cultivos Tipo, Universidad de Valencia, Burjasot, Valencia, Spain.

"The preferred name for Erwinia herbicola is now Pantoea agglomerans.

*Both isolates obtained from identical geographic origin and host.

the Mantel test (Mantel, 1967). Similarity matrices and dendrograms were constructed using NTSYS-pc 2-0 (Exeter Software). To determine the degree of significance, a bootstrap was made using the TFPGA (tools for population genetic analysis) 1-3 software (Efron, 1982; Manly, 1997). 16S rDNA sequences were aligned and a similarity matrix was generated using the method described by Maidak etal. (1996). Dendrograms were obtained using the UPGMA method. 


\section{Development of PCR primers specific for $B$. quercina}

The primer pair REP-a and REP-b with no 5'-label was used to specifically amplify bacterial DNA (Stern et al., 1984) for the detection of $B$. quercina using the above described conditions. Amplified DNA products (10 flh for rep-PCR) were analysed by electrophoresis in $1-5 \%$ agarose gel containing a $0-75 x$ dilution of the standard TAE buffer (Sambrook et al., 1989) and ethidium

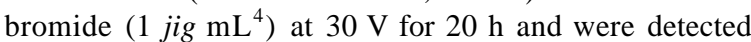
by UV transillumination. A 517-bp DNA fragment specific for $B$. quercina isolates (see Results) was cloned into the pGEM ${ }^{\circledR}-\mathrm{T}$ Easy vector (Promega Corporation), according to the manufacturer's instructions. Two primers, REP-517-a and REP-517-b (sequences 5'-GTCAACATAACAGCGACTAC-3' and 5'-CACGTATCGCATTGATTCTG-3', respectively) (Roche Diagnostics) were designed and synthesized to target the cloned B. quercina REP-amplified fragment.

Specific amplification of the 517-bp fragment was performed using this primer pair and $20 \mathrm{ng}$ of $B$. quercina DNA template in a total reaction volume of $50 \mathrm{flh}$, containing $5 \mathrm{flh}$ of $1 \mathrm{Ox}$ concentrated stock of PCR Gold Buffer with no $\mathrm{MgCl}_{2}$ (Applied Biosystems), $5 \mathrm{jlh}$ of $25 \mathrm{mM} \mathrm{MgCl} \mathrm{M}_{2}$ solution (Applied Biosystems), $8 \mathrm{flh}$ of $10 \mathrm{mM}$ dNTP mix, 04 /iM primers and $2 \mathrm{U}$ of AmpliTaq Gold ${ }^{\mathrm{M}}$. Conditions for amplification were optimized and carried out as follows: an initial denaturation at $95^{\circ} \mathrm{C}$ for $7 \mathrm{~min}$, after which 30 cycles of denaturation $\left(30 \mathrm{~s}\right.$ at $\left.95^{\circ} \mathrm{C}\right)$, primer annealing $\left(30 \mathrm{~s}\right.$ at $\left.60^{\circ} \mathrm{C}\right)$ and primer extension $\left(40 \mathrm{~s}\right.$ at $\left.72^{\circ} \mathrm{C}\right)$ were performed, followed by a final extension at $72^{\circ} \mathrm{C}$ for $10 \mathrm{~min}$ (Hauben et al., 1998b).

The sensitivity of this method was first estimated in bacterial suspensions and on natural samples of acorn oozes by preparing decimal dilutions (from $10^{9}$ to $1 \mathrm{CFU}$ $\mathrm{mL}^{4}$ ) of $B$. quercina cultures in $10 \mathrm{mM} \mathrm{MgCl}_{2}$ buffered saline. These dilutions were used for PCR and plated on $\mathrm{KB}$ medium to determine the cell concentration of $B$. quercina. One millilitre of each dilution was centrifuged (10 $000 \mathrm{~g}$ for $10 \mathrm{~min}$ ) and the bacterial pellet was resuspended in $1 \mathrm{~mL}$ of water. Aliquots $(5 \mathrm{flh})$ were then heated for $5 \mathrm{~min}$ at $95^{\circ} \mathrm{C}$, cooled on ice, and subjected to PCR. To test the validity of this system for the detection of $B$. quercina in infected oak leaves, $100 \mathrm{flh}$ of decimal (from $10^{9}$ to $1 \mathrm{CFU} \mathrm{mL}^{4}$ ) B. quercina dilutions were injected into young Quercus leaves. These dilutions were plated on KB medium to determine the cell concentration of $B$. quercina. After $24 \mathrm{~h}$, the samples were prepared to PCR following the method described by Llop et al. (1999). Negative controls with uninfected plants were included in every DNA extraction series.

\section{Results}

\section{Field sampling}

A total of 38 Quercus samples from several species of trees affected by oak decline were collected in different
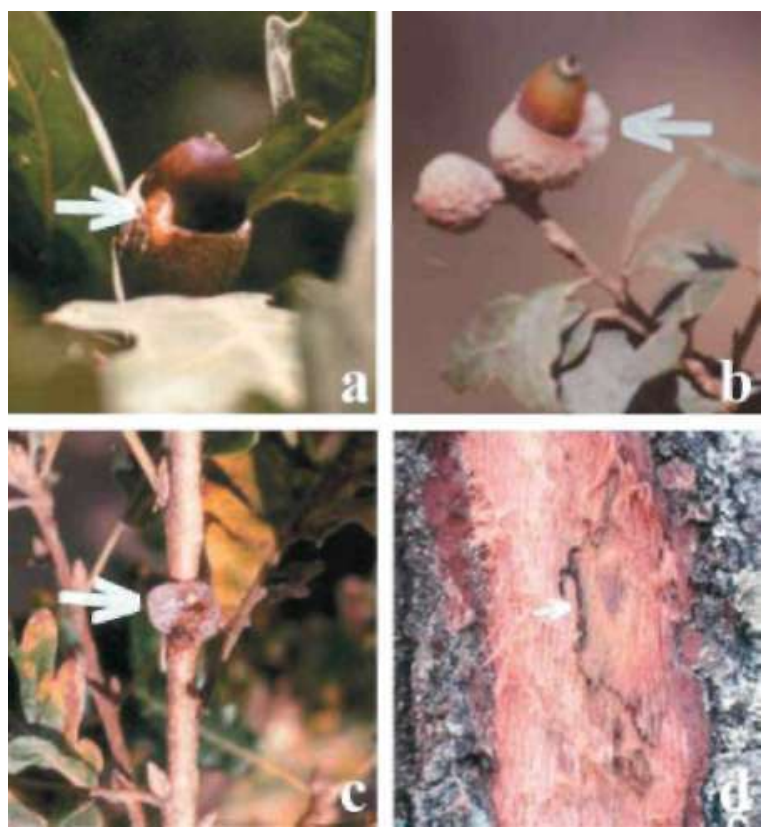

Figure 1 Symptoms of drippy nut disease in naturally infected of Quercus pyrenaica. Damage and/or exudates on the tissues are indicated with arrows, ( $a$ and $b$ ) Acorn cup with oozing typical of the disease, (c) leaf bud with oozing, (d) detail of a 'bleeding canker'.

areas of Spain and bacteria were isolated from the samples (Table 1). Symptoms were found in bark, acorns and buds (Fig. 1). One of the most characteristic symptoms found were canker lesions in the bark of the infected trees. In acorns and buds, the most typical symptom was oozing of plant sap (Fig. 1), which in some cases resulted in acorn abortion (Fig. 1). In more than $90 \%$ of cases a single dominant bacterial type was isolated from the infected tissue. The homogeneity of the colonies was confirmed by analysing an appropriate number of colonies of each isolate with Biolog-GN microplates.

Purified cultures of Brenneria-like colonies, isolated from infected trees, were identified by metabolic profile analysis using Biolog-GN microplates. The results obtained indicated that most isolates, and the corresponding $B$. quercina type strains, had a very similar metabolic profile (Table 2), confirming that the Brenneria-Yike isolates were in fact $B$. quercina. Exceptions were strains $1251-4,1251-5, \mathrm{~N}-78 \mathrm{a}$ and N-78b, which showed similar colony morphology, but differed in the results of some of the tests and formed a homogenous group different from the others (Table 2), although this results was not easily confirmed. It should be noted that in a previous work with the Biolog system (Klingler et al., 1992), when attempts were made to identify Serratia species, the system did not work properly. Similarly, when the group of isolates named as Serratia in the present study were characterized using $16 \mathrm{~S}$ sequencing, the Biolog system was unable to identify them (data not shown). 
Table 2 Metabolic profile characteristics of the Spanish isolates and reference strains of Brennena quercina and Serratia spp. using the Biolog-GN system

Isolate/strain ${ }^{3}$

Carbon source

a-Cyclodextrin

Dextrin

Glycogen

Tween 40

Tween 80

$\mathrm{N}$-Acetyl-D-Galactosamine

N-Acetyl-D-Glucosamine

Adonitol

L-Arabinose

o-Arabitol

o-Cellobiose

i-erythritol

o-Fructose

L-Fucose

D-Galactose

Gentiobiose

a-o-Glucose

m-inositol

a-o-Lactose

Lactulose

Maltose

D-Mannitol

o-Mannose

o-Melibiose

B-Methyl-D-Glucoside

o-Psicose

o-Raffinose

L-Rhamnose

D-Sorbitol

Sucrose

o-Trehalose

Turanose

Xylitol

Pyruvic Acid Methyl Ester

Succinic Acid Mono-Methyl-Ester

Acetic Acid

Cis-Aconitic-Acid

Citric Acid

Formic Acid

D-Galactonic Acid Lactone

o-Galacturonic Acid

o-Gluconic Acid

D-Glucosaminic Acid

D-Glucuronic Acid

a-Hydroxybutyric Acid

B-Hydroxybutyric Acid

y-Hydroxybutyric Acid

p-Hydroxy Phenylacetic Acid
Isolate/strain ${ }^{3}$

Itaconic acid
a-Keto Butyric Acid
a-Keto Glutaric Acid
a-Keto Valeric Acid
D,L-Lactic Acid
Malonic Acid
Propionic Acid
Quinic Acid
o-Saccharic Acid
Sebacic Acid
Succinic Acid
Bromosuccinic Acid
Succinamic Acid
Glucuronamide
L-Alaninamide
o-Alanine
L-Alanine
L-Alanyl-glycine
L-Asparagine
L-Aspartic Acid
L-Glutamic Acid
Glycil-L-Aspartic Acid
Glycil-L-Glutamic Acid
L-Histidine
Hydroxy-L-Proline
L-Leucine
L-Ornithine
L-Phenylalanine
L-Proline
L-Pyroglutamic Acid
o-Serine
L-Serine
L-Threonine
D,L-Carnitine
y-Amino Butyric Acid
Urocanic Acid
Inosine
Uridine
Thymidine
Phenyethyl-amine
Putrescine
2-Aminoethanol
2,3-Butanediol
Glycerol
D,L-a-Glycerol Phosphate
a-o-Glucose-1-Phosphate
D-Glucose-6-Phosphate

Itaconic acid

a-Keto Glutaric Acid

a-Keto Valeric Acid

Succinic Acid

o-Alanine

L-Asparagine

Glycil-L-Aspartic Acid

Glycil-L-Glutamic Acid

L-Histidine

L-Phenylalanine

L-Pyroglutamic Acid

o-Serine

L-Serine

y-Amino Butyric Acid

Urocanic Acid

Thymidine

Phenyethyl-amine

Glycerol

D-Glucose-6-Phosphate

${ }^{\mathrm{a} A}$ A, B. quercina NCPPB 1852; B, B. quercina Spanish isolates (summary of all data); C, 1251-4 and 1251-5 Spanish isolates (summary of all data); $\mathrm{D}, \mathrm{N}-78 \mathrm{a}$ and $\mathrm{N}-78 \mathrm{~b}$ Spanish isolates (summary of all data).

$(+)$ positive in the test, $(-)$ negative in the test and $(=)$ variable in the test.

Pathogenicity assays

The symptoms typical of bacterial canker described by Biosca et al. (2003), were reproduced after inoculation of two Quercus species with bacterial isolates of $B$. quercina and Serratia spp. Quercus Hex and Q. pyrenaica trees were inoculated with two isolates identified as B. quercina (IVIA-1467a and N-77), one isolate 

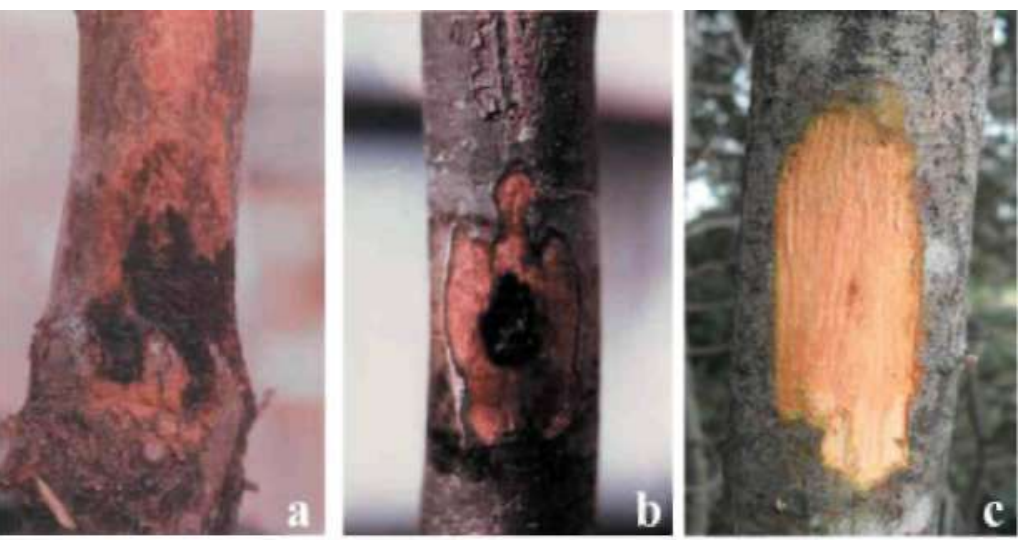

Figure 2 Symptoms 3 months after artificial inoculation of $(a, b, c)$ Quercus pyrenaica and (d, e, f) Q. //exwith (aand d) Brenneria quercina isolate 1467-a $Q$. ilex, respectively, (b and e) Serratia isolate $\mathrm{N}-78$-a or (c and f) $10 \mathrm{miM} \mathrm{MgCl}_{2}$ as a negative control.
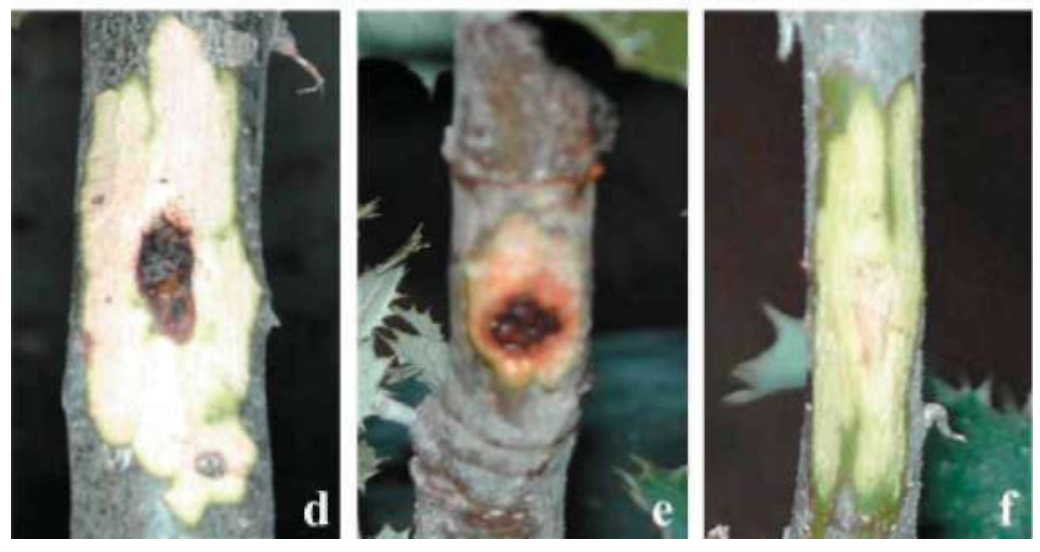

identified as a Serratia spp. (N-78-a) and with $10 \mathrm{mM}$ $\mathrm{MgCl}_{2}$ as a negative control (Fig. 2). Attempts to reisolate the inoculated isolates from bark canker lesions were successful, with identity confirmed by the Biolog system.

\section{Molecular characterization of field isolates}

Molecular profiles from 42 isolates (38 field isolates and four $B$. quercina reference strains) were obtained by rep-PCR and gel electrophoresis (Fig. 5). In addition the bands were separated by capillary electrophoresis and these data were used for further analysis, as described in Materials and methods. To test the reproducibility of the system, the experiments were repeated using identical PCR conditions and DNA from different bacterial cultures obtained under the same experimental conditions. In all cases, the DNA banding pattern obtained was the same. The primer pairs used in this study gave a total of 144 distinct DNA fragments, ranging from $40 \mathrm{bp}$ to $850 \mathrm{bp}$ in length. The numbers of amplified fragments obtained with ERIC and REP primers were 84 and 60, respectively, UPGMA dendrograms produced using data from ERIC and REP primers were very similar; a positive correlation between the ERIC and REP datasets was confirmed using the Mantel test ( ${ }^{\mathrm{ERIC}}$-REP $\left.=0-813\right)$. Therefore, the results from the ERIC and REP systems were combined into a single matrix and a unique dendrogram generated (Fig. 3).
The dendrogram revealed that the $B$. quercina isolates could be differentiated into three groups: clusters I, II and III, whose branches were statistically significant according to the bootstrap test (Nei, 1972) (Fig. 3). Cluster I comprised most of the Spanish field isolates, cluster II included the $B$. quercina reference strains, and cluster III included isolates 1251-4, 1251-5, N-78a and N-78b. Isolates 1251-4 and 1251-5 were both obtained from Q. ilex, from the same focus in Madrid; N-78a and N-78b were obtained from $Q$. pyrenaica, from the same focus in Burgos. These four isolates showed a metabolic profile very different from all the other isolates (Table 2). Moreover, these four could be divided into two subgroups: one corresponding to 1251-4/1251-5, and the other including N-78a/N-78b. These four isolates from cluster III were genetically distant from the other field isolates and from $B$. quercina type strains (Fig. 3).

There was no correlation with host or region within Spain for isolates examined (Fig. 3).

Phylogenetic analyses based on 16S rDNA sequence

The 16S rDNA genes from one selected isolate of the B. quercina group (isolate 1940-1, cluster I; GenBank Ace. No. EF534571) and from two isolates of cluster III (12515, Ace. No. EF534570; and N-78b, Ace. No. EF534572) were amplified and sequenced. A dendrogram based on these sequences and the sequence data available in the Ribosomal Database Project (Larsen et al., 1993) and 


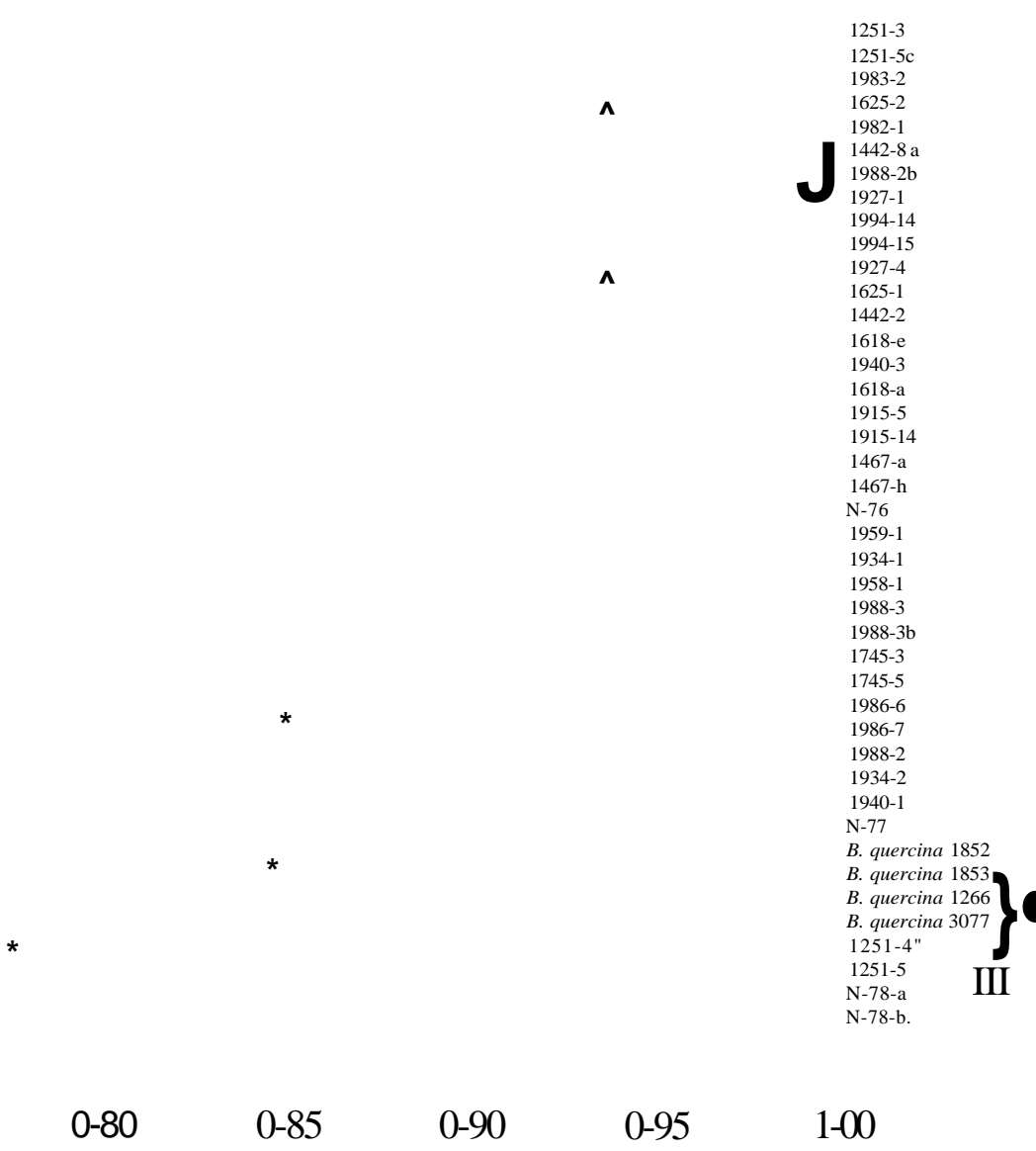

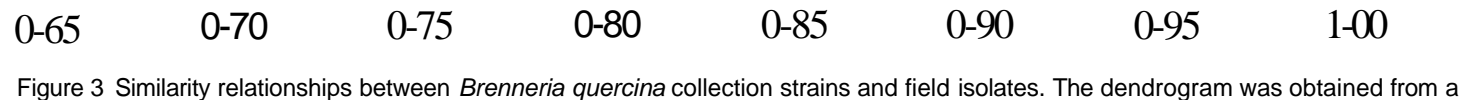
simple-matching similarity matrix generated from the rep-PCR (ERIC and REP PCR primers) system, clustered by UPGMA. The dendrogram combined REP and ERIC datasets. A similarity of $1-0$ indicates $100 \%$ identity between strains. An asterisk indicates that the node is statistically significant at the $95 \%$ level according to the bootstrap method. Group I: Spanish field isolates of $B$. quercina; group II: type-collection strains of B. quercina from California; group III: Spanish field isolates of Serratia.

Hauben et ah (1998a) was built according to the UPGMA method, in order to determine the phylogenetic position of these three isolates within the enterobacterial group. Isolate 1940-1 showed $99-2 \%$ nucleotide similarity to B. quercina $16 \mathrm{~S}$ rDNA, clustering in group III, whereas $\mathrm{N}-78 \mathrm{~b}$ and 1251-5 showed $97-3$ and $97-6 \%$ similarity, respectively with $16 \mathrm{~S}$ rDNA from Serratia rubidaea (DSM 4480 strain) (Fig. 4; Table 3).

\section{Development of a specific PCR protocol for detection} of $B$. quercina

Two DNA fragments of $c .500 \mathrm{bp}$ obtained in rep-PCR fingerprints visualized by gel electrophoresis appeared in all $B$. quercina isolates, whereas they were not present in isolates of other bacteria, including Serratia (Fig. 5). These two fragments were cloned and sequenced; one was selected for further investigation. Primers REP-517-a and REP-517-b were designed for specific amplification of a 517-bp fragment (ace. no. EF534573). The amino acid sequence corresponding to the amplified fragment showed $86 \%$ identity with the DNA repair protein $\mathrm{RecN}$ from Escherichia coli.

To confirm the specificity of the primers, DNA from 57 isolates, comprising 34 field isolates of $B$. quercina, four field isolates of Serratia and 19 reference strains (Table 1) were tested by PCR using primers REP-517-a and REP517-b. Spanish isolates of B. quercina from different geographical origins and recovered in different oak species and Californian isolates yielded a DNA fragment of $517 \mathrm{bp}$, whereas no band resulted from the amplification of the DNA of any of the following bacterial species: E. coli, B. rubrifaciens, B. nigrifluens, B. salicis, B. alni, Pantoea agglomerans, $P$. stewartii, Erwinia herbicola (= Pantoea agglomerans), Pectobacterium carotovorum ssp. atrosepticum, $P$. carotovorum ssp. carotovorum, Erwinia amylovora, E. rhapontici, E. lupinicola, E. mallotivora, Dickeya dadantii and Pseudomonas syringae (data not shown).

The sensitivity of this method was first estimated in bacterial suspensions; the amplification of the 517-bp band was detected on agarose gels down to a bacterial 


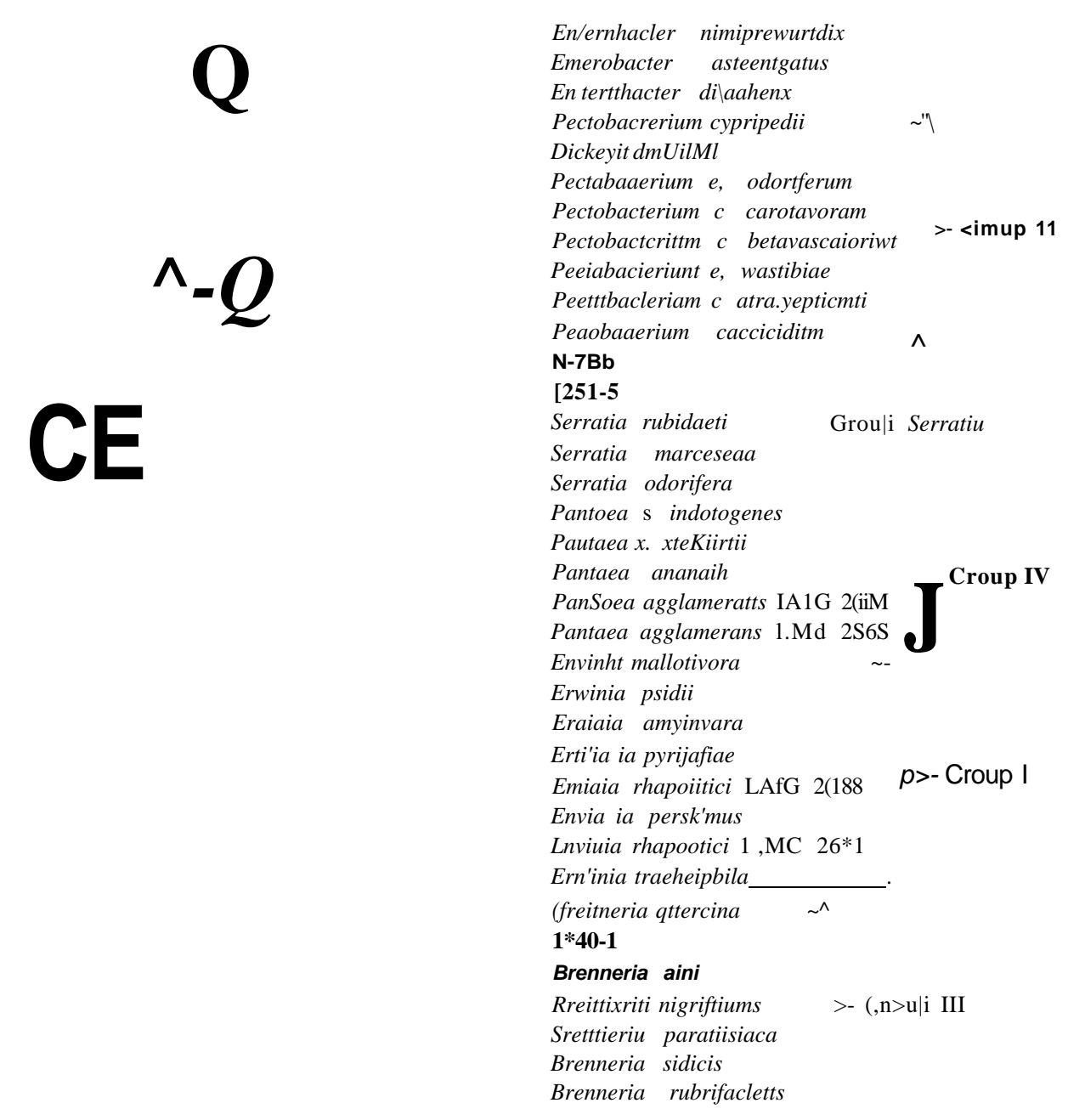

$1 \%$

Figure 4 UPGMA dendrogram depicting the estimated phylogenetic relationships among Enterobactenaceae strains and Serratia strains, based on pairwise comparisons of nearly complete 16S rDNA sequences. 16S rDNA sequences for strains determined in this study are shaded, the rest of the sequence was obtained from the Ribosomal Database Project (Larsen etal., 1993) and from (Hauben etai, 1998a). The distance between two species was obtained by summing the lengths of the connecting horizontal branches using the bottom scale (\% sequence divergence). Group I, II, III and IV represent the genera Erwinia, Pectobacterium, Brenneria and Pantoea, respectively (Hauben etal., 1998a). See Table 3 for expanded names of Group II and IV species.

concentration of $10^{2} \mathrm{CFU} \mathrm{m \textrm {L } ^ { 4 }}$ (Fig. 6a). In natural samples of acorn ooze the detection limit obtained was $10^{2}-10^{3} \mathrm{CFU} \mathrm{mU}^{1}$ (Fig. 6b). This lower sensitivity may have resulted from the chemical complexity of acorn ooze compared with the pure bacterial culture sample. In infected plant material, the amplification of the 517-bp band was detected on agarose gels at all bacterial concentrations above $10^{2} \mathrm{CFUmU}^{1}$ (Fig. 6c).

\section{Discussion}

The genetic diversity of bacteria associated with symptoms of drippy nut and bacterial canker disease in oak forests of the Spain was investigated. DNA profiles of 42 bacterial isolates (38 field isolates and four B. quercina reference strains) from different oak species and from several geographic locations were obtained by rep-PCR, which was combined with a capillary electrophoresis analysis system. A dendrogram differentiated three clusters: cluster I, in which almost all the Spanish isolates were located; cluster II, containing $B$. quercina type strains from California; and cluster III, which contained four Spanish field isolates.

Most of the Spanish isolates (except N-78a, N-78b, 1251-4 and 1251-5) were grouped into cluster I. No significant differences could be found between the branches in this group, indicating a lack of subgroups or subpopulations in the Spanish isolates group. The data from rep-PCR were in accord with those obtained by Biolog identification and 16S rDNA sequence analysis, 
Table 3 Similarity values determined from pairwise comparisons among $16 \mathrm{~S}$ rDNA gene sequences. Shaded grey dates indicate sequences obtained in the present work; remainder are from the Ribosomal Database Project (Larsen etal., 1993) and from Hauben etal. (1998a)

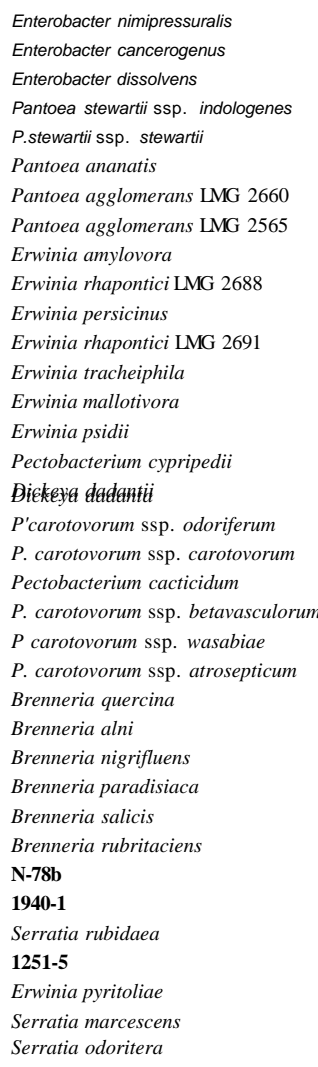

100

98-3 100

$\begin{array}{lll}98-1 & 98-6 \quad 100\end{array}$

96-3 $97-0 \quad 96-6 \quad 100$

$96-4 \quad 97-1 \quad 96-6 \quad 99-5 \quad 100$

$\begin{array}{lllllll}96-3 & 97-1 & 96-1 & 98-1 & 98-3 & 100\end{array}$

$\begin{array}{lllllll}95-7 & 96-2 & 95-5 & 97-0 & 97-2 & 98-3 & 100\end{array}$

95-8 $\quad 96-2 \quad 95-6 \quad 96-9 \quad 97-2 \quad 98-3 \quad 99-3 \quad 1100$

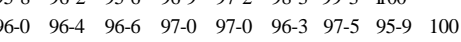

$\begin{array}{llllllllll}96-1 & 96-7 & 96-7 & 96-1 & 96-4 & 95-8 & 95-7 & 95-8 & 97-7 & 1100\end{array}$

$\begin{array}{llllllllllll}96-0 & 96-8 & 96-8 & 95-9 & 96-2 & 95-6 & 96-0 & 96-2 & 97-6 & 99-0 & 100\end{array}$

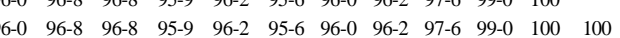

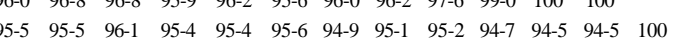

94-9 $95-6 \quad 96-3 \quad 96-5 \quad 96-6 \quad 96-0 \quad 95-7 \quad 95-8 \quad 97-1 \quad 96-8$ 96-6 $96-6 \quad 95-4 \quad 100$

$\begin{array}{llllllllllllllll} & 95-2 & 96-0 & 96-4 & 96-8 & 96-8 & 96-1 & 96-0 & 95-6 & 96-4 & 96-0 & 95-7 & 95-7 & 96-0 & 97-6 & 100 \\ 95-7 & 97-1 & 96-2 & 95-7 & 95-8 & 95-7 & 94-7 & 94-6 & 96-0 & 96-7 & 96-3 & 96-3 & 94-2 & 95-4 & 94-7 & 100\end{array}$

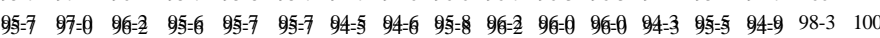

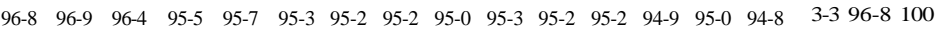

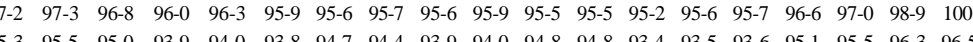

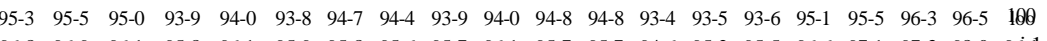

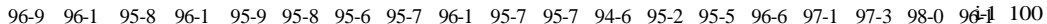

$\begin{array}{lllllllllllllllllllllll}96-5 & 96-9 & 96-1 & 95-1 & 95-4 & 95-1 & 95-5 & 95-7 & 95-5 & 96-5 & 96-8 & 96-8 & 94-5 & 95-3 & 94-4 & 97-1 & 97-5 & 97-8 & 98-1 & 97-2 & 98-1 & 100 & \end{array}$

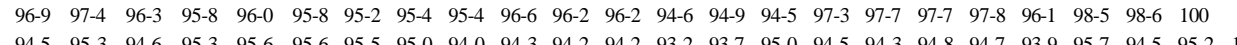

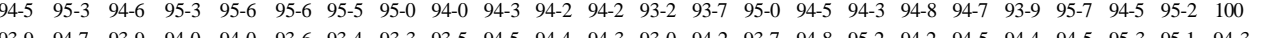

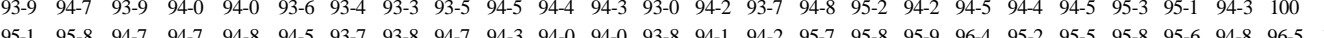

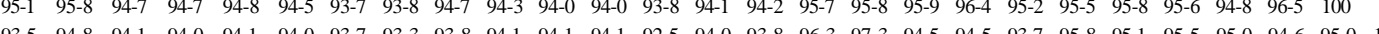

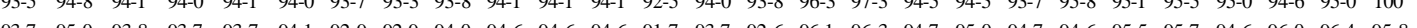

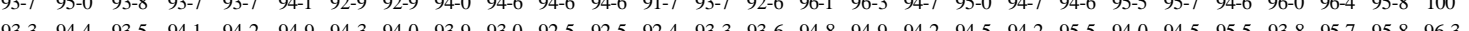

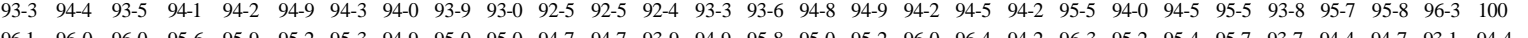

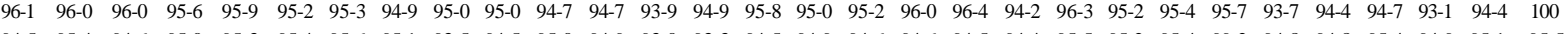

$\begin{array}{lllllllllllllllllllllllllllllll}94-5 & 95-4 & 94-6 & 95-0 & 95-3 & 95-4 & 95-6 & 95-1 & 93-5 & 94-5 & 95-0 & 94-9 & 93-0 & 93-3 & 94-5 & 94-9 & 94-6 & 94-6 & 94-5 & 94-4 & 95-5 & 95-2 & 95-4 & 99-2 & 94-8 & 94-8 & 95-4 & 94-9 & 95-1 & 95-5 & 100\end{array}$

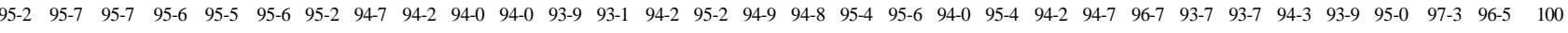

$\begin{array}{lllllllllllllllllllllllllllllllllll}96-0 & 96-0 & 96-3 & 95-7 & 95-6 & 95-2 & 94-7 & 94-2 & 95-0 & 94-7 & 94-8 & 94-8 & 93-5 & 94-8 & 95-4 & 95-2 & 95-4 & 95-7 & 95-9 & 94-0 & 96-0 & 95-0 & 95-5 & 95-6 & 93-9 & 94-0 & 95-1 & 93-7 & 94-0 & 98-4 & 95-3 & 97-6 & 100 & \end{array}$

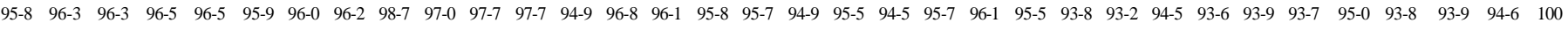

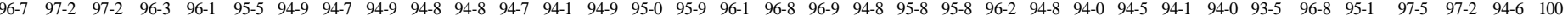

Serratia odoritera

$\begin{array}{lllllllllllllllllllllllllllllllllllllllll}96-0 & 96-7 & 96-3 & 95-5 & 95-4 & 95-2 & 94-4 & 94-3 & 95-2 & 94-6 & 94-7 & 94-7 & 94-2 & 94-7 & 94-3 & 95-6 & 96-3 & 96-3 & 96-0 & 94-8 & 95-9 & 95-7 & 96-2 & 94-9 & 94-4 & 94-6 & 94-3 & 94-2 & 93-7 & 96-0 & 94-8 & 97-0 & 96-8 & 95-1 & 97-8 & 1\end{array}$ 


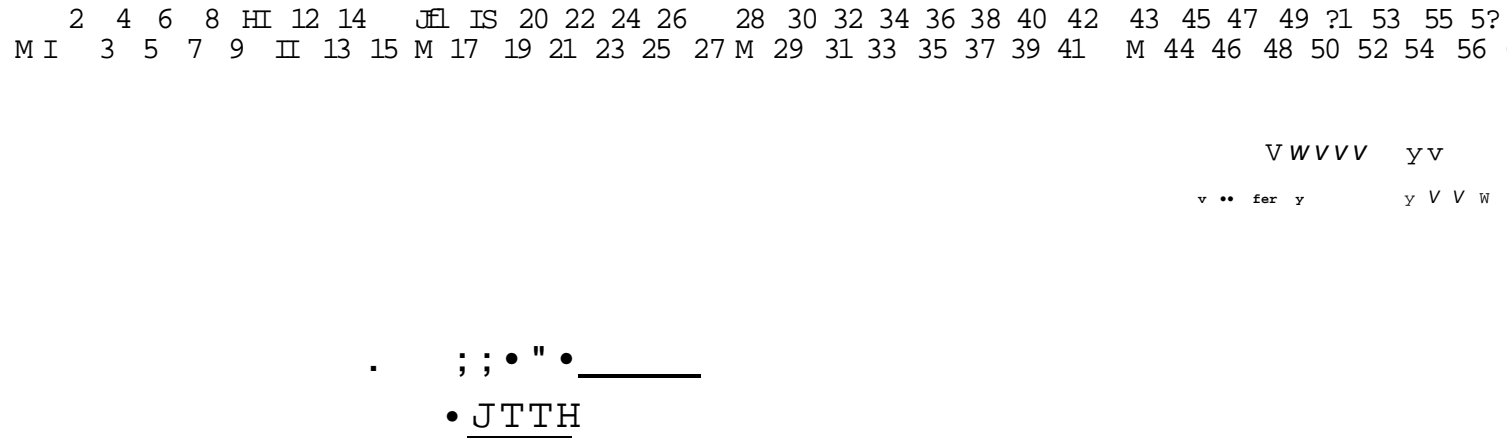

Figure 5 Rep-PCR fingerprint patterns of genomic DNA from field isolates and type collection strains. PCR product patterns were generated using the REP primers listed in the text. Lanes 1-15: type-collection strains: (1) Erwinia herbicola NCPPB 2971; (2) Pantoea stewartii2994; (3) P. agglomerans 1742-5; (4) £ amylovora NCPPB 595; (5) £ rhapontici 1093-1a; (6) £ mallotivora 1818; (7) Dickeya dadantii AC4150; (8) Pectobacterium carotovorum ssp. carotoi/orum312; (9) fi carotovorum ssp. atrosepticum SCRI 1001; (10) Brenneria alni NCPPB 3934; (11)0. nigrifluens NCPPB 564; (12) 0 . sa//c/s NCPPB 447; (13) 0. rubrifaciens NCPPB 2020; (14) £ lupinicola 3299; (15) fi syringae pv. tomato DC 3000. Lanes 16-57: field isolates and type-collection strains from 0. quercina: (16) 1251-4; (17) 1251-5; (18) 1251-3; (19) 1251-5c; (20) N-76; (21) N-77; (22) N-78a; (23) N-78b; (24) 0. quercina CFBP 1266; (25) 0. quercina 1852; (26) 0. quercina 1853; (27) 0. quercina 3077; (28) 1442-2; (29) 1442-8a; (30) 1467-a; (31) 1467-h; (32) 1618-a; (33) 1618-e; (34) 1625-1; (35) 1625-2; (36) 1745-3; (37) 1745-5; (38) 1915-5; (39) 1915-14; (40) 1927-1; (41) 1927-4; (42) 1934-1; (43) 1934-2; (44) 1940-1; (45) 1940-3; (46) 1958-1; (47) 1959-1; (48) 1982-1; (49) 1983-2; (50) 1986-6; (51) 1986-7; (52) 1988-2b; (53) 1988-2; (54) 1988-3b; (55) 1988-3; (56) 1994-14; (57) 1994-15. Lane C, negative control. Lane M, 100-bp DNA Ladder Plus molecular size marker GeneRulerTM (MBI Fermentas). The size of the two DNA fragments used as diagnostic tools (boxed) was $500-600$ bp.

indicating that most of the Spanish isolates corresponded to B. quercina. Moreover, these B. quercina Spanish isolates were closely related to other Brenneria spp., such as $B$. alni, $B$. nigrifluens and $B$. salicis, whose natural hosts are woody plants (Hauben et al., 1998a). Although the samples were collected in different geographic areas of Spain and from different oak species, no clear relation could be found between strains and geographic origins and/or natural hosts. The fact that $B$. quercina reference strains from California belonged to a different cluster than the B. quercina Spanish field strains, suggests a divergence between these groups of isolates but further data will be needed to investigate the origin of Spanish isolates of $B$. quercina.

Cluster III contained Spanish isolates N-78a, N-78b, 1251-4 and 1251-5 and was genetically distant from the $B$. quercina isolates in cluster I. 16S rDNA sequences from these strains were compared with previously reported data (Kwon et al., 1997; Hauben et al., 1998a). Isolates N-78b and 1251-5 showed 97-3 and 97-6\% similarity, respectively, to the $S$. rubidaea type strain. When the other $B$. quercina field isolates were subjected to the same analysis, $99-2 \%$ similarity to B. quercina type strain was obtained. The $16 \mathrm{~S}$ rDNA sequence analysis clearly showed that strains N-78a, N-78b, 1251-4 and 1251-5 belonged to the genus Serratia.

Certain pathogenic bacteria have a wide range of hosts and can be found in several niches. For example, Fantoea agglomerans (formerly Erwinia herbicola/Enterobacter agglomerans) is associated with plants as an epiphyte or a pathogen, but can also be found as an opportunistic pathogen in humans. Serratia sp. is also an opportunistic human pathogen that can be found in plants (Grimont et al., 1977; Grimont \& Grimont, 1984). Serratia species are phylogenetically close to the former Erwinia genus, which included Brenneria (Grimont et al., 1977; Hauben et al., 1998a; Sproer et al., 1999). Different virulence systems have been described in Serratia which share common features with other bacterial phytopathogens, such as the $P$. carotovorum hexA gene, implicated in the regulation of pectolytic enzymes (Harris et al., 1998) or the $S$. marcescens rap gene, homologous to the Erwinia hor genes, which has been implicated in the regulation of antibiotic production and exo-enzymes, which in turn are involved in pathogenicity (Thomson et al., 1997).

Pathogenicity tests suggested that the Spanish $B$. quercina and Serratia isolates are able to survive and grow on oak trees, and to produce bark symptoms. Also, the fact that the studied isolates satisfied Koch's postulates supports the hypothesis that both bacteria are causal agents of oak disease. The pathogenicity of Brenneria is well described (Hildebrand \& Schroth, 1967; Biosca et al., 2003), whereas Serratia has not been previously reported as a plant pathogen. The data point to the possibility of the latter isolates being pathogens of trees, but confirmation between field symptoms and Serratia isolates it is still required. Alternatively Serratia spp. may be secondarily associated with infected oaks as a saprophyte and displaces $B$. quercina at later stages of the disease.

Additionally in this work, PCR primers have been developed for the specific detection of B. quercina in 
(a)

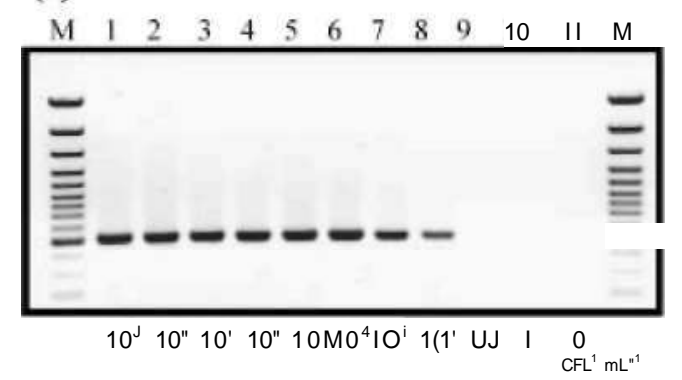

(b)

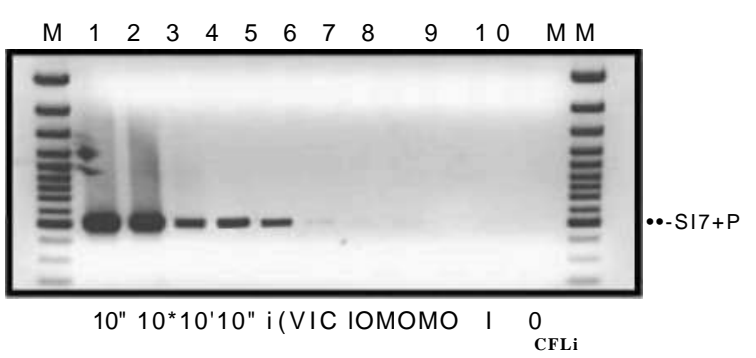

(c)

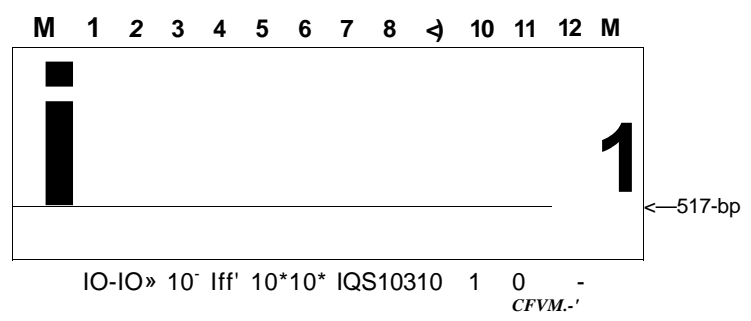

Figure 6 Sensitivity test for PCR-based detection of Brenneria quercina using primers REP-517-aand REP-517-b. (a) Sensitivity of the method in the analysis of pure culture samples of $B$. quercina field isolate 1940-1; lanes 1-10, PCR-amplified products obtained with decreasing concentrations of bacteria from $10^{9}$ to $1 \mathrm{CFU} \mathrm{ml} \sim^{1}$; lane 11 , PCR-negative control; lane M, 100-bp DNA Ladder Plus molecular size marker, (b) Sensitivity of method in analysis of ooze from acorns; lanes 1-10, PCR-amplified products obtained with decreasing concentrations of bacteria from $10^{9}$ to $1 \mathrm{CFU} \mathrm{ml} \sim^{1}$; lane 11 , PCR-negative control; laneM, 100-bp DNA Ladder Plus molecular size marker. The size of the diagnostic product (arrowed) was $517 \mathrm{bp}$. (c) Sensitivity of method in analysis of Quercus pyrenaica leaves inoculated with of $B$. quercina (field isolate 1940-1); lanes 1-10, PCR-amplified products obtained with decreasing concentrations of bacteria from $10^{9}$ to $1 \mathrm{CFU} \mathrm{mL}^{1}$ of plant extract; lane 11 , PCR-negative control; lane 12, non-inoculated plant material; lane M, 100-bp DNA Ladder Plus molecular size marker.

liquid culture, acorn ooze and inoculated Quercus leaves. The specificity of these primers was demonstrated by absence of amplification of the unique fragment in 16 bacterial species phylogenetically related to $B$. quercina (including $E$. coli), although the possibility cannot be excluded that another bacterial field isolate could yield a positive result. Clearly, the specificity of the primers is not caused by the absence of the sequence corresponding to the $\operatorname{rec} N$ gene, since this gene is widely conserved among the enteric bacteria. The data indicate that the sensitivity of the method is high, enabling the detection of $B$. quercina in concentrations as low as $10^{2} \mathrm{CFU} \mathrm{mL}^{4}$. This sensitivity is in line with other reports using PCR-based detection methods (Hauben et al.,1998b; Penyalver et al., 2000). These are the first primers for the specific detection and identification of $B$. quercina and will be useful for the diagnosis of this pathogen in plant material showing symptoms and for the detection of its epiphytic and endophytic presence, which may improve knowledge of the epidemiology of this poorly studied bacterium.

\section{Acknowledgements}

We gratefully acknowledge Dr S. Soria (Patrimonio Nacional, Spain) for the generous supply strains and isolates supplied and Dr M. Milgroom (Cornell University, NY), Dr R. Raposo (INIA, Spain), Dr E. Lopez-Solanilla (ETSIA-UPM, Spain), Dr L. M. Rubio (University of California-Berkeley, CA) and Dr S. E. Lindow (University of California-Berkeley, CA) for the critical reading of this manuscript. We also thank Dr D. Garcia (Coleccion Espanola de Cultivos Tipo (CECT), Universidad de Valencia, Spain) for the type strains of the Serratia ssp. provided. We acknowledge Carlos Rojas and Joaquin Garcia-Guijarro for technical assistance. This work was financed by the Ministry of Education and Science, Project BIO-2005-07198 and by grant 1FD97-0911-C0302 of the FEDER programme from the EU.

\section{References}

Altschul SF, Madden TL, Schaffer AA et al., 1997. Gapped BLAST and PSI-BLAST: a new generation of protein database search programs. Nucleic Acids Research 25, 3389-402.

Barionovi D, Giorgi S, Stoeger AR, Ruppitsch W, Scortichini M, 2006. Characterization of Erwinia amylovora strains from different host plants using repetitive-sequences PCR analysis, and restriction fragment length polymorphism and short-sequence DNA repeats of plasmid pEA29. Journal of Applied Microbiology 100, 1084-94.

Biosca EG, Gonzalez R, Lopez-Lopez MJ et al., 2003. Isolation and characterization of Brenneria quercina, causal agent for bark canker and drippy nut of Quercus spp. in Spain. Phytopathology 93, 485-92.

Brown EW, Davis RM, Gouk C, van der Zwet T, 2000. Phylogenetic relationships of necrogenic Erwinia and Brenneria species as revealed by glyceraldehyde-3-phosphate dehydrogenase gene sequences. International Journal of Systematic and Evolutionary Microbiology 50, 2057-68.

Dawson SL, Fry JC, Dancer BN, 2002. A comparative evaluation of five typing techniques for determining the diversity of fluorescent pseudomonads. Journal of Microbiological Methods 50, 9-22.

Efron B, 1982. The Jackknife, the Bootstrap and Other Resampling Plans. Philadelphia, PA, USA: Society for Industrial and Applied Mathematics.

Grimont PA, Grimont F, De Rosnay HC, 1977. Taxonomy of the genus Serratia. Journal of General Microbiology 98 , 39-66. 
Grimont PAD, Grimont F, 1984. Genus VIII. Serratia Bizio 1823, 288AL. In: Krieg NR, ed. Bergey's Manual of Systematic Bacteriology. Baltimore, MD, USA: Williams \& Wilkins, 477-84.

Hanahan D, 1983. Studies on transformation of Escherichia coli with plasmids. Journal of Molecular Biology 166, 557-70.

Harris SJ, Shih YL, Bentley SD, Salmond GP, 1998. The hexA gene of Erwinia carotovora encodes a LysR homologue and regulates motility and the expression of multiple virulence determinants. Molecular Microbiology 28, 705-17.

Hauben L, Vauterin L, Swings J, Moore ERB, 1997. Comparison of $16 \mathrm{~S}$ ribosomal DNA sequences of all Xanthomonas species. International Journal of Systematic Bacteriology 47, 328-35.

Hauben L, Moore RB, Vauterin L, Steenackers M, Mergaert J, 1998a. Phylogenetic position of phytopathogens within the Enterobacteraceae. International Journal of Systematic and Applied Microbiology 21, 384-97.

Hauben L, Steenackers M, Swings J, 1998b. PCR-based detection of the causal agent of watermark disease in willows (Salix spp.). Applied and Environmental Microbiology 64, 3966-71.

Hildebrand DC, Schroth MN, 1967. A new species of Erwinia causing the drippy nut disease of live oaks. Phytopathology $57,250-3$.

Hulton CS, Higgins CF, Sharp PM, 1991. ERIC sequences: a novel family of repetitive elements in the genomes of Escherichia coli, Salmonella typhimurium and other Enterobacteriaceae. Molecular Microbiology 5, 825-34.

King EO, Ward MK, Rainey DE, 1954. Two simple media for the demonstration of pyocyanin and fluorescein. Journal of Laboratory and Clinical Medicine 44, 301-7.

Klingler JM, Stowe RP, Obenhuber DC, Groves TO, Mishra SK, Pierson DL, 1992. Evaluation of the Biolog automated microbial identification system. Applied and Environmental Microbiology 58, 2089-92.

Kwon SW, Go SJ, Kang HW, Ryu JC, Jo JK, 1997. Phylogenetic analysis of Erwinia species based on 16S rRNA gene sequences. International Journal of Systematic Bacteriology 47, 1061-7.

Larsen N, Olsen GJ, Maidak BL et al, 1993. The ribosomal database project. Nucleic Acids Research 21, 3021-3.

Llop P, Caruso P, Cubero J, Morente C, Lopez MM, 1999. A simple extraction procedure for efficient routine detection of pathogenic bacteria in plant material by polymerase chain reaction. Journal of Microbiology Methods 37,23-31.

Louws FJ, Fulbright DW, Stephens CT, de Bruijn FJ, 1994. Specific genomic fingerprints of phytopathogenic Xanthomonas and Pseudomonas pathovars and strains generated with repetitive sequences and PCR. Applied and Environmental Microbiology 60, 2286-95.
Maidak BL, Olsen GJ, Larsen N, Overbeek R, McCaughey MJ, Woese CR, 1996. The ribosomal database project (RDP). Nucleic Acids Research 24, 82-5.

Manly BJF, 1997. Randomization, Bootstrap, and MonteCarlo Methods in Biology, 2nd edn. London, UK: Chapman \& Hall.

Mantel N, 1967. Adaptation of Karber's method for estimating the exponential parameter from quantal data, and its relationship to birth, death, and branching processes. Biometrics 23, 739-46.

Nei M, 1972. Genetic distance between populations. American Naturalist 106,283-92.

Penyalver R, Garcia A, Ferrer A, Bertolini E, Lopez MM, 2000. Detection of Pseudomonas savastanoi pv. savastanoi in olive plants by enrichment and PCR. Applied and Environmental Microbiology 66, 2673-7.

Ribbeck-Busch K, Roder A, Hasse D et al., 2005. A molecular biological protocol to distinguish potentially human pathogenic Stenotrophomonas maltophilia from plantassociated Stenotrophomonas rhizophila. Environmental Microbiology 7, 1853-8.

Sambrook J, Fritsch EF, Maniatis T, 1989. Molecular Cloning: a Laboratory Manual, 2nd edn. Cold Spring Harbor, New York, USA: Cold Spring Harbor Laboratory Press.

Sneath PHA, Sokal RR, 1973. Numerical Taxonomy. San Francisco, CA, USA: W H. Freeman.

Soria S, Lopez MM, Lopez Lopez MJ, 1997. Presencia, sintomatologia y danos de Erwinia quercina en Espana y su posible relacion con la 'seca de la encina'. Ecologia 11, 295-301.

Sproer C, Mendrock U, Swiderski J, Lang E, Stackebrandt E, 1999. The phylogenetic position of Serratia, Buttiauxella and some other genera of the family Enterobacteriaceae. International Journal of Systematic Bacteriology 49,1433-8.

Stern MJ, Ames GF, Smith NH, Robinson EC, Higgins CF, 1984. Repetitive extragenic palindromic sequences: a major component of the bacterial genome. Cell 37, 1015-26.

Thomson NR, Cox A, Bycroft BW, Stewart GSAB, Williams P, Salmond GPC, 1997. The Rap and Hor proteins of Erwinia, Serratia and Yersinia: a novel subgroup in a growing superfamily of proteins regulating diverse physiological processes in bacterial pathogens. Molecular Microbiology 26, 531-44.

Versalovic J, Koeuth T, Lupski JR, 1991. Distribution of repetitive DNA sequences in eubacteria and application to fingerprinting of bacterial genomes. Nucleic Acids Research 19, 6823-31.

Young JM, Park DC, 2007. Relationships of plant pathogenic enterobacteria based on partial atpD, car $A$, and recA as individual and concatenated nucleotide and peptide sequences. Systematic and Applied Microbiology 30, 343-54.

Young JM, Park DCh, Weir BS, 2004. Diversity of 16S rDNA sequences of Rhizobium spp. implications for species determinations. FEMS Microbiology Letters 238, 125-31. 